\title{
SCIDiC
}

\author{
International Journal of Dentistry and Oral Science (IJDOS) \\ ISSN: 2377-8075
}

\section{Prevalence Of Anterior Strip Crowns Among Carious Primary Teeth}

Research Article

\author{
J. Chandra Pooja ${ }^{1}$, Subramanian $\mathrm{EMG}^{2 *}$, Ganesh Jeevanandan ${ }^{3}$ \\ ${ }^{1}$ Saveetha Dental College and Hospitals, Saveetha Institute of Medical and Technical Sciences, Chennai - 600 077, TN, India. \\ ${ }^{2}$ Professor, Department Of Pedodontics, Saveetha Dental College, Saveetha Institute of Medical and Technical Sciences, Saveetha University, 162, \\ Poonamallee High Road, Chennai - 600077, Tamil Nadu, India. \\ ${ }^{3}$ Reader, Department of Pedodontics, Saveetha Dental College and Hospitals, Saveetha Institute of Medical and Technical Sciences (SIMATS) Saveetha \\ University, Chennai, India.
}

\section{Abstract}

\begin{abstract}
In case of congenital malformation, discoloration of teeth suffered from trauma or congenitally and teeth with amelogenesis imperfecta and post pulpectomy strip crowns are given .Strip crowns are transparent plastic crowns with varying sizes. The aim of the study is to evaluate the prevalence strip crowns were preferred for a carious primary teeth.A retrospective study was carried out using case records of 199 patients who reported to the Department of Pedodontics from June 2019 to March 2020.The various cases where strip crowns were preferred for treatment were observed from the digital records and tabulated on a spreadsheet. The collected data was analysed by computer software SPSS version 21 using Chi square test with the level of significance with age,gender of patients who selected strip crowns. The patients who took strip crowns were $51.8 \%$ other treatment for anterior carious primary tooth was $48.2 \%$.The strip crowns were taken as a treatment of choice for anterior primary carious teeth after pulpectomy and it was prevalently used among male children in the age group of 3 to 5 years of age. Both age and gender of the children had no significant association with strip crowns as a treatment of choice.
\end{abstract}

Keywords: Amelogenesis Imperfecta; Congenital Malformation; Pulpectomy; Strip Crowns.

\section{Introduction}

Dental caries is the single most common chronic childhood disease affecting worldwide.Poor oral hygiene and dental plaque is one of the aetiological factors in causation of dental caries [1]. It has been shown to have a multifactorial etiology which leads to the initiation and progression of the lesion [2]. In early childhood caries there is early pulp involvement and gross destruction of maxillary anterior teeth as well as posterior teeth. The major concern in the field of paediatric dentistry is the loss of primary teeth despite various efforts available in the prevention of dental caries in children [3]. One of the main reason for extensive caries are decreased fluoride concentration leads to increased risk of caries $[4,5]$. Treatment of such caries represents a challenge to paediatric dentistry especially when the teeth are badly destroyed [6]. The retention and preservation of the primary tooth in the dental arch in its normal function and free of pathology is of utmost importance [7].

Pulpectomy procedure is performed in primary teeth to avoid extraction and to maintain its form and function [8] and a conservative treatment approach that retains and preserves the primary tooth in the dental arch and non-pathologic state until its exfoliation [9]. Rotary instrumentation in pediatric dentistry is an emerging concept [10]. Using rotary instruments for primary tooth pulpectomies resulted in better and predictable root canal filling [11]. Nickel-Titanium (Ni-Ti) instruments are available to perform efficient root canal preparation in primary teeth [12].

Aesthetic restoration of such carious primary teeth in children has been an ongoing challenge for the paediatric and general dentist while the most effective aesthetic materials and techniques for restoring deciduous teeth are still questioned. With the advancement of dental materials and techniques in conservative

*Corresponding Author:

Subramanian EMG

Professor, Department Of Pedodontics, Saveetha Dental College, Saveetha Institute of Medical and Technical Sciences, Saveetha University, 162, Poonamallee High Road, Chennai - 600077, Tamil Nadu, India.

E-mail: subramaniam@saveetha.com

Received: May 28, 2021

Accepted: June 16, 2021

Published: July 05, 2021

Citation: J. Chandra Pooja, Subramanian EMG, Ganesh Jeevanandan. Prevalence Of Anterior Strip Crowns Among Carious Primary Teeth. Int J Dentistry Oral Sci. 2021;8(7):30503054. doi: http://dx.doi.org/10.19070/2377-8075-21000621

Copyright: Subramanian EMG ${ }^{\circ} 2021$. This is an open-access article distributed under the terms of the Creative Commons Attribution License, which permits unrestricted use, distribution and reproduction in any medium, provided the original author and source are credited. 
dentistry, a multitude of aesthetic treatment modalities have been introduced for the management of dental caries and trauma in the primary dentition [13]. Since primary teeth play an imperative role in the self-esteem of the preschool children and also plays a pivotal role in speech development, esthetics, and function [14].

In case of severely decayed primary incisors with minimal enamel remaining for bonding, subgingival caries, and uncontrolled moisture and hemorrhage, stainless steel crowns are there restoration used $[15,16]$ and for the primary interest is the most aesthetic treatment of choice used in composite resin crown type of crown was first introduced in 1979 by Weber and colleagues [17].

The indications for strip crowns include extensive decay of primary anterior teeth, fractured or malformed teeth, teeth that exhibit discoloration and as a coverage for teeth that have received pulp therapy. Composite resin strip crowns are now widely accepted because of them being better thick as they assemble more closely by natural appearance of teeth [18, 19]. There are numerous reports and articles in the intra tcia that describe the technique for placement of these crowns [20]. The composite reason is a polymerized, the celluloid crown form is peeled off or "stripped" with a hand scalar, the remaining composite resin is finished at the margins and polished using a burn [21, 22].

Strip crowns are composed of celluloid crown forms that act as matrix forms to fill with tooth coloured materials. Usually their crowns are restored with a written based composite to allow for selection of shades to match the adjacent teeth and provide an excellent ascetic outcome. Resin modified ionomer cement has been used for the material as an interim restoration in younger children $[23,24]$. Previously our team has a rich experience in working on various research projects across multiple disciplines $[4,25,26,1$, $16,27,36]$. The aim of the study is to evaluate the use of strip crowns in the primary anterior teeth and its prevalence among different age groups and gender.

\section{Materials And Method}

\section{Study design and Study setting}

The present study was conducted in a hospital in Chennai to evaluate the patients who got strip crowns after pulpectomy, from June 2019 to March 2020. The retrospective study was carried out with the help of digital case records of 199 children that reported to the dental hospital for treatment. Since it is a retrospective study, carried out using digital case records, no informed consent was required from the patient. Ethical clearance to conduct this study was obtained from the Scientific Review Board of the hospital.All retrospective studies arising from the patient records set between 01 June 2019 and 31 march 2020 will be covered by the following ethical approval number. SDC/SIHEC/2020/DIASDATA/0619-0320.

\section{Sampling}

The type of study was Retrospective. The data of 199 children were reviewed and then extracted. Only relevant data was included to minimize bias. Non probability sampling method was carried out. Cross verification of data for errors was done with the help of clinical photographs. The study contained regional data generalised to the South Indian population.

\section{Data Collection}

A single calibrated examiner evaluated the digital case records of the 199 patients from June 2019 to March 2020 and reviewed the crowns fabricated after for the patients after pulpectomy. They were categorised into strip crowns and other treatments. The internal validity of the study was among pedo patients who underwent pulpectomy. External validity of the study was to educate the patients on the advantages strip crowns over the other crowns. Inclusion criteria was anterior teeth with extensive caries which required pulpectomy followed by crown fabrication. Exclusion criteria included posterior teeth requiring pulpectomy.

\section{Statistical Analysis}

The collected data was validated, tabulated and analysed with Statistical Package for SocialSciences for Windows, version 20.0 (SPSS Inc., Chicago, IL, USA) and results were obtained. Categorical variables were expressed in frequency and percentage; and continuous variables in mean and standard deviation. Chi-square test was used to test associations between categorical variables. Chi Square tests were carried out using demographic data like age and gender as independent variables and patient willingness and condition of the teeth as the dependent variable. $\mathrm{P}$ value $<0.05$ was considered statistically significant.

\section{Results And Discussion}

This study was carried out among 199 patients to evaluate prevalence of strip crowns in the primary anterior teeth post pulpectomy. The prevalence among different age groups and gender was evaluated. Out of 199 patients $51.76 \%$ of children got strip crowns and $48.24 \%$ of children got crowns other than strip crowns namely stainless steel, figaro and zirconia. Chi-square test was done between the treatment opted with age and gender. Below the age group of 2 years $6.53 \%$ of patients had strip crowns and $5.53 \%$ of patients had other types of crown. Between the age group of $3-5$ years $42.21 \%$ of patients had $42.21 \%$ and $37.19 \%$ had crowns other than strip crowns. Above the age group of 5 years $3.02 \%$ of patients had strip crowns and $5.53 \%$ of patients had other types of crowns. Regarding the gender, in male patients $31.16 \%$ of patients had strip crowns and $27.14 \%$ had other crowns and in female patients $20.60 \%$ of patients had strip crowns and $21.11 \%$ of patients had crowns other than strip crowns.

The results of the study show (Figure 1) that for the treatment of anterior pulpectomy the most fabricated crown was anterior strip crowns, the results of the study is similar to Kupietzly a et al [37] who reported that parental satisfaction with bonded resin composite strip crown for the treatment of primary incisors with multi surface carious lesion was higher. The results were also similar to a study by Divya subramaniyam and Ganesh Jeevanandan [38] which stated that parental satisfaction with treatment of both kids' stip crown and 3mespe crown were found to be satisfactory with no significant difference. Both crowns had similar clinical success rate at the end of the month follow up. KIDS strip crowns can be cost effective restoration option to be used in primary maxillary anterior teeth. 
Figure 1. Bar chart depicting frequency of strip crowns fabricated compared to other crowns. $\mathrm{X}$ axis represents the crown fabricated and $\mathrm{Y}$ axis represents the number of children who underwent pulpectomy.51.76\% of patients got strip crowns after pulpectomy(Red colour). $48.24 \%$ of the patients got crowns other than strip crowns after pulpectomy(Yellow colour).

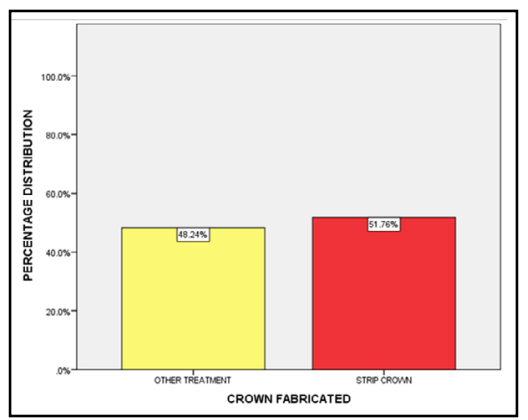

Figure 2. Bar chart depicting association between age of patients with crown fabricated. $X$ axis represents age of patients and $\mathrm{Y}$ axis represents number of patients with crown fabricated after pulpectomy. Highest number of strip crowns (green) were fabricated in patients between the age of 3-5 years compared to other treatment .Chi square analysis done. $\mathrm{p}=$ $0.36(p>0.05)$, statistically not significant. Hence there is no significant association.

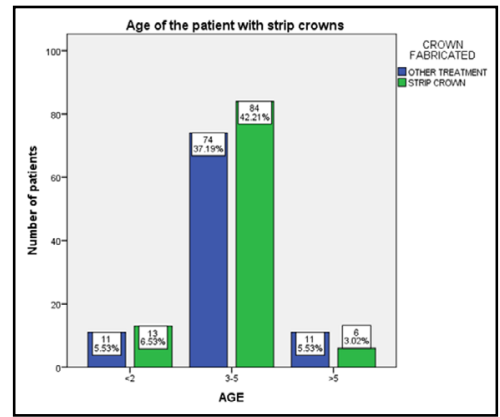

Figure 3. Bar chart depicting association between gender of patients with crown fabricated. $X$ axis represents gender of patients and $\mathrm{Y}$ axis represents number of patients with crown fabricated after pulpectomy. Highest number of strip crowns(green) were fabricated among male patients compared to female patients. Chi square analysis done. $\mathrm{p}=$ $0.57(p>0.05)$,statistically not significant.Hence there is no significant association.

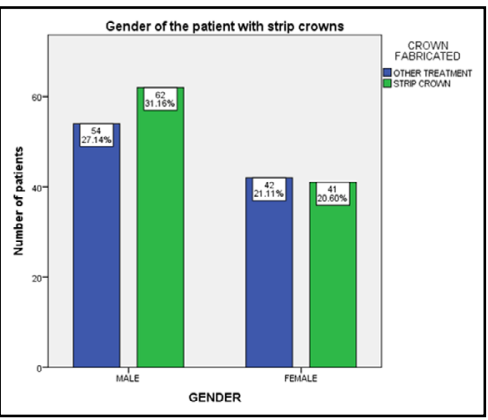

The results of the study show (Figure 2) that strip crowns were most preferred among the age group of 3-5 years. This is similar to the study by Tremblay L et al. [39] which stated that a very young child is often neglected by the dentist while choosing a treatment plan. However, recent work in psychology has shown that consciousness about self can begin as early as 3-5 years of age and a study by Sharat Chandra Pani et al. [40], findings of which showed that while children from a young age were able to appreciate and have an opinion about dental esthetics, their opinion often agrees with that of their parents.

According to the study results (Figure 3) gender has no significance correlation with strip crowns as a treatment of choice and male patients has got more strip crowns than female patients. The results are dissimilar to Mon Mon Tin Ooet et al [41], which says dissatisfaction with tooth colour is significantly higher in female than male patients [odds ratio for 1.99, 95\% confidence interval-1.B-3.50], hence female patients prefer strip crowns which is more aesthetic. The result might change with different population and sample sizes.

By the result of the study it can be seen that strip crowns are the most commonly preferred crown over other crowns in case of exterior multi surface caries due to its durability aesthetics case of treatment and it being a cost effective mode of treatment. The limitations of the study include very less sample size and small geographical location with the period of study conducted being short.Our institution is passionate about high quality evidence based research and has excelled in various fields [42-52].

\section{Conclusion}

Within the limitation of the study, it can be concluded that strip crowns were more preferred over other crowns for the treatment of anterior carious primary teeth because of its superior esthetics, ease of use and durability. The strip crowns were found to be used 
in case of large or multi surface caries for better retention and was prevalently used in male children between the age of 3-5 years.

\section{Author Contribution}

Author 1 (J.Chandrapooja) carried out the retrospective study by collecting data and drafted manuscript performing the necessary statistical analysis. Author 2 (Dr.Subramaniam EMG) aided in the conception of the topic, participated in the study design, statistical analysis and coordinated in developing the manuscript and author 3 (Dr.Ganesh Jeevanandan) aided in coordinating and developing the manuscript. All the authors have contributed in developing the manuscript.

\section{Acknowledgement}

The authors would like to acknowledge the support of the department of Pedodontics and information technology of saveetha dental college and Hospitals and the management for their constant assistance with the research.

\section{References}

[1]. Govindaraju L, Gurunathan D. Effectiveness of Chewable Tooth Brush in Children-A Prospective Clinical Study. J Clin Diagn Res. 2017 Mar;11(3):ZC31-ZC34.Pubmed PMID: 28511505.

[2]. Subramanyam D, Gurunathan D, Gaayathri R, Vishnu Priya V. Comparative evaluation of salivary malondialdehyde levels as a marker of lipid peroxidation in early childhood caries. Eur J Dent. 2018 Jan-Mar;12(1):67-70. Pubmed PMID: 29657527.

[3]. Jeevanandan G, Govindaraju L. Clinical comparison of Kedo-S paediatric rotary files vs manual instrumentation for root canal preparation in primary molars: a double blinded randomised clinical trial. Eur Arch Paediatr Dent. 2018 Aug;19(4):273-278.Pubmed PMID: 30003514.

[4]. Somasundaram S, Ravi K, Rajapandian K, Gurunathan D. Fluoride Content of Bottled Drinking Water in Chennai, Tamilnadu. J Clin Diagn Res. 2015 Oct;9(10):ZC32-4.Pubmed PMID: 26557612

[5]. Ramakrishnan M, Shukri M. Fluoride, Fluoridated Toothpaste Efficacy And Its Safety In Children-Review. Int. J. Pharm. Sci. Res. 2018 Oct $1 ; 10(04): 109-14$.

[6]. Muhamad AH, Azzaldeen A, Mai A. Strip crowns technique for restoration of primary anterior teeth: case report. J Med Dent Sci. 2015;14(12):48-53.

[7]. Panchal V, Jeevanandan G, Subramanian E. Comparison of instrumentation time and obturation quality between hand $\mathrm{K}$-file, $\mathrm{H}$-files, and rotary Kedo-S in root canal treatment of primary teeth: A randomized controlled trial. J Indian Soc Pedod Prev Dent. 2019 Jan-Mar;37(1):75-79.Pubmed PMID: 30804311

[8]. Govindaraju L, Jeevanandan G, Subramanian EM. Knowledge and practice of rotary instrumentation in primary teeth among indian dentists: A questionnaire survey. Int. J. Oral Health. 2017 Mar 1;9(2):45.

[9]. Lakshmanan L, Mani G, Jeevanandan G, Ravindran V, Ganapathi SE. Assessing the quality of root canal filling and instrumentation time using kedos files, reciprocating files and k-files. Braz. Dent. Sci. 2020 Jan 31;23(1):7.

[10]. Govindaraju L, Jeevanandan G, Subramanian EMG. Comparison of quality of obturation and instrumentation time using hand files and two rotary file systems in primary molars: A single-blinded randomized controlled trial. Eur J Dent. 2017 Jul-Sep;11(3):376-379.Pubmed PMID: 28932150.

[11]. Jeevanandan G. Kedo-S Paediatric Rotary Files for Root Canal Preparation in Primary Teeth - Case Report. J Clin Diagn Res. 2017 Mar;11(3):ZR03ZR05.Pubmed PMID: 28511532

[12]. Govindaraju L, Jeevanandan G, Subramanian E. Clinical Evaluation of Quality of Obturation and Instrumentation Time using Two Modified Rotary File Systems with Manual Instrumentation in Primary Teeth. J Clin Diagn Res. 2017 Sep;11(9):ZC55-ZC58.Pubmed PMID: 29207834.

[13]. Muhamad AH, Nezar W, Azzaldeen A, Hanali AS. Anterior dental esthetics in primary teeth. Int J Environ Res Public Health. 2015;3(1):25-36.

[14]. Ravikumar D, Jeevanandan G, Subramanian EM. Evaluation of knowledge among general dentists in treatment of traumatic injuries in primary teeth: A cross-sectional questionnaire study. Eur J Dent. 2017 Apr;11(02):232-7.

[15]. Croll TP. Bonded composite resin crowns for primary incisors: technique update. Quintessence Int. 1990 Feb 1;21(2):153-7.

[16]. Gurunathan D, Shanmugaavel AK. Dental neglect among children in Chennai. J Indian Soc Pedod Prev Dent. 2016 Oct 1;34(4):364-9.

[17]. Croll TP, Helpin ML. Preformed resin-veneered stainless steel crowns for restoration of primary incisors. Quintessence Int. 1996 May;27(5):309-13. Pubmed PMID: 8941812.

[18]. Croll TP. Restorative dentistry for preschool children. Dent Clin North Am. 1995 Oct 1;39(4):737-70

[19]. Packiri S, Gurunathan D, Selvarasu K. Management of paediatric oral ranula: a systematic review. J Clin Diagn Res. 2017 Sep;11(9):ZE06-9.

[20]. Webber DL, Epstein NB, Wong JW, Tsamtsouris A. A method of restoring primary anterior teeth with the aid of a celluloid crown form and composite resins. Pediatr Dent. 1979 Dec;1(4):244-6.Pubmed PMID: 298766.

[21]. Waggoner WF. Restorative dentistry for the primary dentition. In pediatric dentistry: Infancy through adolescence, Pinkham JR, Ed. Philadelphia: WB Saunders Co; 1994.

[22]. Aishwarya A, Gurunathan D. Stress level in dental students performing pedodontic procedure. J Adv Pharm Educ Res. 2017;7(1).

[23]. Jeong MA, Kim AH, Shim YS, An SY. Restoration of strip crown with a resin-bonded composite cement in early childhood caries. Case Rep Dent. 2013;2013:581934.Pubmed PMID: 24490090.

[24]. Nelson T. An improved interim therapeutic restoration technique for management of anterior early childhood caries: report of two cases. Pediatr Dent. 2013 Jul-Aug;35(4):124-8.Pubmed PMID: 23930627.

[25]. Hafeez N. Accessory foramen in the middle cranial fossa. Res J Pharm Technol. 2016;9(11):1880-2.

[26]. Krishnan RP, Ramani P, Sherlin HJ, Sukumaran G, Ramasubramanian A, Jayaraj G, et al. Surgical Specimen Handover from Operation Theater to Laboratory: A Survey. Ann Maxillofac Surg. 2018 Jul-Dec;8(2):234-238. Pubmed PMID: 30693238.

[27]. Felicita AS. Orthodontic extrusion of Ellis Class VIII fracture of maxillary lateral incisor - The sling shot method. Saudi Dent J. 2018 Jul;30(3):265269.Pubmed PMID: 29942113.

[28]. Kumar S, Rahman R. Knowledge, awareness, and practices regarding biomedical waste management among undergraduate dental students. Asian J Pharm Clin Res. 2017;10(8):341.

[29]. Sneha S. Knowledge and awareness regarding antibiotic prophylaxis for infective endocarditis among undergraduate dental students. Asian J Pharm Clin Res. 2016 Oct 1:154-9.

[30]. Dhinesh B, Lalvani JI, Parthasarathy M, Annamalai K. An assessment on performance, emission and combustion characteristics of single cylinder diesel engine powered by Cymbopogon flexuosus biofuel. Energy Convers. Manag. 2016 Jun 1;117:466-74.

[31]. Choudhari S, Thenmozhi MS. Occurrence and Importance of Posterior Condylar Foramen. Res J Pharm Technol. 2016;9(8):11-43.

[32]. Paramasivam A, Vijayashree Priyadharsini J, Raghunandhakumar S. N6adenosine methylation $(\mathrm{m} 6 \mathrm{~A})$ : a promising new molecular target in hypertension and cardiovascular diseases. Hypertens Res. 2020 Feb;43(2):153154.Pubmed PMID: 31578458.

[33]. Wu F, Zhu J, Li G, Wang J, Veeraraghavan VP, Krishna Mohan S, et al. Biologically synthesized green gold nanoparticles from Siberian ginseng induce growth-inhibitory effect on melanoma cells (B16). Artif Cells Nanomed Biotechnol. 2019 Dec;47(1):3297-3305.Pubmed PMID: 31379212.

[34]. Palati S, Ramani P, Shrelin HJ, Sukumaran G, Ramasubramanian A, Don KR, et al. Santhanam A. Knowledge, Attitude and practice survey on the perspective of oral lesions and dental health in geriatric patients residing in old age homes. Indian J Dent Res. 2020 Jan-Feb;31(1):22-25.Pubmed PMID: 32246676.

[35]. Saravanan M, Arokiyaraj S, Lakshmi T, Pugazhendhi A. Synthesis of silver nanoparticles from Phenerochaete chrysosporium (MTCC-787) and their antibacterial activity against human pathogenic bacteria. Microb Pathog. 2018 Apr;117:68-72.Pubmed PMID: 29427709.

[36]. Vijayakumar Jain S, Muthusekhar MR, Baig MF, Senthilnathan P, Loganathan S, Abdul Wahab PU, et al. Evaluation of Three-Dimensional Changes in Pharyngeal Airway Following Isolated Lefort One Osteotomy for the Correction of Vertical Maxillary Excess: A Prospective Study. J Maxillofac Oral Surg. 2019 Mar;18(1):139-146.Pubmed PMID: 30728705.

[37]. Kupietzky A, Waggoner WE, Galea J. Long-term photographic and radiographic assessment of bonded resin composite strip crowns for primary incisors: results after 3 years. Pediatr Dent. 2005 May-Jun;27(3):221-5.Pubmed PMID: 16173227.

[38]. Subramanyam D, JeevananDan G. Comparison of Parental Satisfaction and Clinical Evaluation of KIDS Strip Crown Versus 3M ESPE Crown in Primary Anterior Teeth-An Invivo Study. J Clin Diagn Res. 2018 Aug 1;12(8):ZC9-11.

[39]. Tremblay L, Lovsin T, Zecevic C, Larivière M. Perceptions of self in 3-5-year-old children: a preliminary investigation into the early emergence 
of body dissatisfaction. Body Image. 2011 Jun;8(3):287-92.Pubmed PMID: 21600861.

[40]. Pani SC, Saffan AA, AlHobail S, Bin Salem F, AlFuraih A, AlTamimi M. Esthetic Concerns and Acceptability of Treatment Modalities in Primary Teeth: A Comparison between Children and Their Parents. Int J Dent. 2016;2016:3163904.Pubmed PMID: 27446212.

[41]. Tin-Oo MM, Saddki N, Hassan N. Factors influencing patient satisfaction with dental appearance and treatments they desire to improve aesthetics. BMC oral health. 2011 Dec;11(1):6.

[42]. Vijayashree Priyadharsini J. In silico validation of the non-antibiotic drugs acetaminophen and ibuprofen as antibacterial agents against red complex pathogens. J Periodontol. 2019 Dec;90(12):1441-1448.Pubmed PMID: 31257588

[43]. Pc J, Marimuthu T, Devadoss P, Kumar SM. Prevalence and measurement of anterior loop of the mandibular canal using CBCT: A cross sectional study Clin Implant Dent Relat Res. 2018 Apr 6;20(4):531-4.

[44]. Ramesh A, Varghese S, Jayakumar ND, Malaiappan S. Comparative estimation of sulfiredoxin levels between chronic periodontitis and healthy patients - A case-control study. J Periodontol. 2018 Oct;89(10):1241-1248.Pubmed PMID: 30044495.

[45]. Ramadurai N, Gurunathan D, Samuel AV, Subramanian E, Rodrigues SJ. Effectiveness of $2 \%$ Articaine as an anesthetic agent in children: randomized controlled trial. Clin Oral Investig. 2019 Sep;23(9):3543-50.

[46]. Sridharan G, Ramani P, Patankar S, Vijayaraghavan R. Evaluation of salivary metabolomics in oral leukoplakia and oral squamous cell carcinoma. J Oral Pathol Med. 2019 Apr;48(4):299-306.
[47]. Ezhilarasan D, Apoorva VS, Ashok Vardhan N. Syzygium cumini extract induced reactive oxygen species-mediated apoptosis in human oral squamous carcinoma cells. J Oral Pathol Med. 2019 Feb;48(2):115-121.Pubmed PMID: 30451321.

[48]. Mathew MG, Samuel SR, Soni AJ, Roopa KB. Evaluation of adhesion of Streptococcus mutans, plaque accumulation on zirconia and stainless steel crowns, and surrounding gingival inflammation in primary molars: randomized controlled trial. Clin Oral Investig. 2020 Sep;24(9):1-6.Pubmed PMID: 31955271

[49]. Samuel SR. Can 5-year-olds sensibly self-report the impact of developmental enamel defects on their quality of life? Int J Paediatr Dent. 2021 Mar;31(2):285-286.Pubmed PMID: 32416620.

[50]. R H, Ramani P, Ramanathan A, R JM, S G, Ramasubramanian A, et al. CYP2 C9 polymorphism among patients with oral squamous cell carcinoma and its role in altering the metabolism of benzo[a]pyrene. Oral Surg Oral Med Oral Pathol Oral Radiol. 2020 Sep;130(3):306-312.Pubmed PMID: 32773350.

[51]. Chandrasekar R, Chandrasekhar S, Sundari KKS, Ravi P. Development and validation of a formula for objective assessment of cervical vertebral bone age. Prog Orthod. 2020 Oct 12;21(1):38.Pubmed PMID: 33043408.

[52]. Vijayashree Priyadharsini J, Smiline Girija AS, Paramasivam A. In silico analysis of virulence genes in an emerging dental pathogen A. baumannii and related species. Arch Oral Biol. 2018 Oct;94:93-98.Pubmed PMID: 30015217. 